\title{
ANALYSIS OF PERCEIVED SAFETY IN URBAN PARKS: A FIELD STUDY IN BÜYÜKPARK AND HASANAĞA PARK İlknur TÜRKSEVEN DOĞRUSOY*, Rengin ZENGEL*
}

Received: 19.02.2015; Final Text: 23.09.2016

Keywords: Urban parks, perceived safety, Büyükpark, Hasanağa Park, İzmir.
* Department of Architecture, Faculty of Architecture, Dokuz Eylül University, İzmir, TURKEY.

\section{INTRODUCTION}

Perception of safety is an important factor that shape approach and avoidance behaviors of park users and may be evaluated either as a facilitator or an inhibitor for park use. Available recreation resources like urban parks are good for users' psychological well-being and physical health. However, when safety issues have been disregarded while designing parks, this may discourage many potential visitors from using and enjoying these public open spaces. Researchers have recently shown that lack of safety sometimes causes park users to avoid using the parks and making their physical activities when being alone (Bedimo-Rung et al., 2005). Additionally, some studies have reported that park users are reluctant to use where areas of a park make them feel unsafe and, as a consequence of this, they prefer using safer parks more frequently than less safe ones (Marcus and Francis, 1998; Schroeder and Anderson, 1984; Van Herzele and Wiedemann 2003; Westover, 1985). Especially fear of crime has been found as a major factor restraining the use of public parks in relation to safety (Madge, 1997). However, there are some studies that have contradictory results stating that urban parks with lower ratings of safety have frequently been used by inhabitants than parks with higher safety ratings due to programming and staffing (Cohen et al., 2009).

Recent studies have mainly concentrated on some of the issues that affect sense of safety. While some of these studies have focused on psychological or socio demographic variables (Farrall et al., 2000; Hale, 1996), some of them have highlighted the importance of physical and environmental factors (Herzog and Chernick, 2000; Nasar and Fisher, 1993; Nasar and Jones, 1997). These studies, most of which are experimental studies, have investigated perceived safety in relation to fear of crime. So far, there is no research that develops a scale to measure perceived safety and clarify other crucial dimensions explaining perceived safety beyond fear of crime with an on-site study conducted in urban parks. The aim of this study is to fill 
these gaps and conduct a field study by examining the relations among some important factors and perceived safety in a broader sense.

The leading research questions are as follows;

1. What is the meaning of perceived safety in urban parks? Which are the main factors that explain perceived safety?

2. What is the relationship between perceived safety of park users and environmental design properties of urban parks? Which environmental and design characteristics of urban parks enhance perceived safety?

3. Which demographic and perceptual factors are significant in relation to perceived safety?

4. What is the relationship between perceived safety and park use?

The research started with review of previous related studies and determination of crucial factors related to perceived safety. Then, the samples and instruments, including the scale developed to measure perceived safety, and the procedure of the field study have been developed and results have been discussed with reference to the literature review.

\section{LITERATURE REVIEW}

In this section, factors affecting the sense of safety have been reviewed under three categories such as environmental, perceptual and demographic factors.

\section{Environmental Factors for Perceived Safety}

\section{Environmental Design}

Environmental design is the most commonly studied factor in relation to perceived safety in urban environments. Appleton's (1975) "Prospect and Refuge Theory" stressed the importance of good environmental design in order to enhance sense of safety. This theory suggests that sustaining victims' ability to see possible threats and offenders around without being seen by them improved victim's sense of safety. Some researchers enhanced the theory by determining preferred design characteristics to improve perceived safety such as lack of hiding places and increase in depth of view (Nasar et al., 1993; Schroeder and Anderson, 1984).

Physical boundaries of an environment can limit the prospect and possibility for potential victims to escape and can make hiding places for potential offenders. When possibilities to escape are low, the fear of crime can be high (Fisher and Nasar, 1992; Nasar and Jones, 1997). It is important to design enclosures of parks to meet safety and privacy needs, while not preventing the users to leave the parks in case of fear of crime. Therefore, fences and existence of buffer zones in parks that restricts park users to leave immediately when needed may provoke fear of crime and cause lower sense of safety, as Stamps' (2005) experimental study supports. Connected with this, long view distance and access to nearby streets and buildings are important to enhance sense of safety and security (Müderrisoğlu and Demir, 2004). It should be argued that in some cases, visual and physical enclosures of parks may provide restorative effects, when users would like to be alone in nature, probably because of control, safety or privacy needs (Nordh and Østby, 2013). Previous studies have mainly concentrated on the relations between fear of crime and perceived 
safety and wayfinding anxiety has not been studied as a factor to explain sense of safety. However, wayfinding anxiety may be another important dimension of perceived safety, since perception of personal safety and wayfinding strategy are related to wayfinding anxiety in previous studies (Lawton and Kallai, 2002). Additionally, a number of design features such as signboards, visual access to the outside, architectural differentiation, and floor plan configuration that have not been studied previously may also influence legibility and wayfinding anxiety (Weisman, 1981).

Landscape Design, Maintenance, Lighting and Security Precautions

Many researchers have stated that good green design enhances perceived safety in parks. These are improving visibility at the ground level by reducing the height of shrubs and enclosing walls, raising the tree canopies and supplying grass or smooth ground together with water elements, and decreasing tree density (Forsthy et al., 2005; Schroeder and Anderson 1984; Talbot and Kaplan, 1984; Westover, 1986; Müderrisoğlu and Demir, 2004; Thompson, 2002). In addition to green design properties, general design characteristics of parks may also affect sense of safety. For instance, formally designed manicured parks have been found safer than more natural looking ones (Özgüner and Kendle, 2006). Maintenance of green areas is another reported issue for sense of safety. Well-designed and maintained flowerbeds and shrubberies have enhanced feelings of both safety and attractiveness in urban parks (Bixler and Floyd, 1997; Shaffer and Anderson, 1985). On the other hand, graffiti and litter have decreased perceived safety ratings in parks (Schroeder and Anderson, 1984).

Additionally, increased overall background activity both in parks (Marcus and Francis, 1998) and surrounding neighborhoods is an important factor to help people to feel less intimidated and feel safer, since being alone evokes fear in some people (Crewe, 2001).

Among the environmental features relevant to safety and security, lighting is the most frequently mentioned factor (Loewen et al., 1993). Warr (1990) have found that darkness increases fear of crime. Additionally, positive opinions about daytime safety have been shared among all age groups in Crewe's (2001) study. Good lighting is not only considered a facilitator in enhancing perceived safety but also accepted as one of the most common solutions for crime prevention by design (Atkins et al., 1991; Lab, 2000). Security precautions such as guards, police, close circuit television cameras (CCTV) or rule signs are also important to develop user's sense of safety, since they decrease fear of crime in urban parks. Generally, related research concentrated on crime prevention by CCTVs in different kinds of public spaces (Welsh and Farrington, 2009; Gill and Spriggs, 2005; Phillips, 1999). Previous studies indicate that there is actually little evidence showing the crime prevention impact of CCTVs (Isnard, 2001), and even confirm the minor effects of CCTVs on actual crime prevention (Lawlink, 2000). In contrast, fear-reduction potential of CCTVs has been noted by public attitude surveys, over long term showing that residents believe in the effectiveness of CCTVs in reducing fear of crime. Since perceived and actual safety is somewhat different from each other and the latter is related to the perceptions of people, security precautions can be important to enhance park user's sense of safety. 


\section{Perceptual Factors Associated with Perceived Safety}

Crowding

Being alone is a factor that may evoke personel fear in some cases. Özgüner and Kendle (2006) found that presence of other people may positively affect the feeling of safety. One possible reason for this is that people believe others in immediate vicinity will come to help in case of an attack (Warr, 1990). Especially females reported that they rarely visit the parks because of fear of crime, unless they are with a group of people (Westover, 1986). However, sometimes other group members may cause fear instead of enhancing sense of safety. It all depends on the number, characteristics and behaviors of the others (Jorgensen et al., 2002). Unruly and antisocial behaviors of some people or potential criminals like gangs, drug users, and homeless people around may provoke feelings of fear and sometimes even existence of other people can be an irritating factor for sense of safety.

Wayfinding anxiety

Stress and anxiety, commonly experienced by newcomers,accompany disorientation in both buildings and natural environments (Cohen et al., 1986) and this may lead to wayfinding anxiety. However, there is limited research investigating the relations between disorientation, wayfinding anxiety and perceived safety. Lawton and Kallai's (2002) cross cultural study regarding gender differences have showed that feeling of personal safety and wayfinding strategy mediates the gender difference in wayfinding anxiety. Additionally, Weisman (1987) suggested that degree of architectural legibility can affect sense of control and safety in emergency situations. The relations among architectural legibility, wayfinding anxiety and feelings of safety need to be studied in the case of urban parks.

\section{User Satisfaction}

Appleton (1975) suggests that perceived safety is related to the aesthetic pleasure taken from the environment as an important dimension of user satisfaction. For residential environments, both empirical and survey studies indicate that neighborhood safety is related to both housing and surrounding neighborhood satisfaction (Baba and Austin, 1989; Austin et al., 2002). In another research, fear of crime, which is an important dimension of perceived safety, has been found as a negative factor for environmental satisfaction (Pain, 1997). Loukaitou-Sideris and Stieglitz (2002) demonstrate that most children have been satisfied and felt themselves safe in the parks regardless of regions. However, a few children who have been unsatisfied with their parks, mentioned about safety issues like presence of undesirable people (drunks and gangsters) and their unruly behaviors, in addition to environmental factors such as low maintenance and unqualified equipments in the parks. Although the relation between environmental satisfaction and perceived safety were studied by many researchers, Graefe et al. (2000) stress that safety related issues in parks show confusing results and suggest further studies to identify different meanings of safety in relation to visitor satisfaction.

Familiarity

Familiarity with an environment is related to the knowledge of bad or good reputations of public spaces (Harden, 2000) and develops with frequent visitations, imaginations and memories about a place (Relph, 1976). Familiarity is also a factor affecting environmental preference (Herzog et al., 1976) and wayfinding in natural environments (Kaplan, 1976). Harden 
(2000) emphasize that familiarity may affect sense of safety and Warr (1990) states novelty as a key variable provoking fear of criminal victimization. Other researchers such as Jorgensen et al. (2002) discuss how familiar people in a park setting can develop coping strategies with the others who may affect their safety and comfort levels. In contrast, Westover (1985) found that familiarity with a park have not strongly been associated with either sense of safety or reported avoidance.

\section{Demographic Factors Associated with Perceived Safety}

Gender and age are the most studied demographic factors in relation to fear of crime in both residential and public environments. Westover (1985) described a link between fear of crime and avoidance behavior of park visitors regarding gender. In this study, female respondents who feel unsafe, reported more avoidance behavior than males. When age factor is considered, elderly people have been found more fearful of crime than young people and have avoided to use the parks where crime is perceived as a problem, although the risk of victimization for them is low (Ferraro and La Grange, 1987; Godbey and Blazey, 1983; Ortega and Myles, 1987). This result can be explained by physical inefficiencies of the elderly. In contrast to results of many other studies, Mc Coy et al. (1996) found out that elderly people did not have high levels of fear.

There are confusing results for the relations among income, education and fear of crime. Some studies found no relationship between income, education and fear of crime in urban parks (Westover, 1985). However, other studies conducted in neighborhoods found that residents with low levels of education reported higher levels of fear than people with higher levels of education (Scarborough et al., 2010). Marital status has not been studied as a factor to perceived safety in the previous research conducted in urban parks. However, it can be an important factor in urban parks since being married can be a positive factor for perceived safety especially for woman. Marriage may encourage to use parks with a partner or a member of the family which enhance sense of safety, whereas being alone or single may provoke fear of crime, provoke wayfinding anxiety and reduce environmental satisfaction.

\section{METHOD OF THE RESEARCH}

A comparative research strategy has been used to achieve the aims of this research. The two parks have been selected among urban parks of İzmir as cases of the study after a careful assessment. One of the cases, which is the Büyükpark located in Bornova neighborhood, is selected as it represents the positive environmental properties regarding safety. The second case, which is the Hasanağa Park located in Buca neighborhood, is used as a comparative sample as it has most of the negative environmental properties in terms of safety.

\section{Properties of Samples}

İzmir is the third biggest city located in the western part of Turkey. The city has a mild and rainy climate during winter and a dry and hot climate during summer, which makes the use of public open spaces very important. After Republican Period (1923), gardens of private residences, previously used as open spaces, were transformed first into public promenades (bahçe's) and then to public parks. The cases of the study were opened to public use after Republican period in İzmir. One of the samples, 
Büyükpark, was transformed from a cemetery to urban park in 1934, and the other Hasanağa Park was transformed from a private garden of a Levantine house to an urban park in 1926.

Location in the City

The locations of the two selected urban parks in İzmir are different. While Büyükpark is located within Bornova city center, Hasanağa Park is located between the old town and urban edge of Buca district. Büyükpark is completely surrounded by mixed uses such as shops, cafes, restaurants at ground level on top of which residential uses take place. The park constitutes a shortcut between different regions of the city center with plenty of public facilities. The ground activities in the surrounding neighborhood of Büyükpark are more vivid during the day and the night, when compared to Hasanağa Park. Surrounding neighborhood of Hasanağa Park lacks the activities especially during night time. While the northwestern and northeastern sides of Hasanağa Park face educational facilities, the southwestern side is next to an urban transformation area inhabited mostly by immigrants with lower education and income from the eastern regions of Turkey. Transformation area has still some slums and is on the exit of İzmir-Aydın highway. Both parks are accessible by pedestrians and public transportation vehicles (Figure 1, Figure 2).

Environmental Design and Landscape

Environmental design of the two case study parks are different from each other. Büyükpark has a modernist, well defined and a legible layout with an ornamental pool at the centre. Hasanağa Park has an organic layout design transferred from its early garden use and been composed of curvilinear and connected but somewhere discontinuous paths. Büyükpark has four continuous and diagonally intersected paths that connect central area to the exits of the park and surrounding neighborhood by sustaining physical and visual access. Besides, the park is well accessed from all sides by pedestrians since it has got no buffer zones. However, one third of Hasanağa Park cannot be reached directly from the surrounding neighborhood because of the existing historical walls at northwest and the wire nettings at southeast, which may prevent people to leave easily in case of safety issues (Figure 1, Figure 2).

There is a well defined landmark that leads one of the exits in the park, a statue of Atatürk, just across the ornamental pool located at the center of Büyükpark. On the contrary, the bird cage, organically shaped ornamental pool, and Public Security Branch Office constitute vague reference points in Hasanağa Park (Figure 3). Just across the statue, the main entrance of Büyükpark is well defined when compared to the ones in Hasanağa Park (Figure 4). When Büyükpark is a small park with 38,150 square meter surface area which may enhance wayfinding, Hasanağa Park is approximately three times bigger than the former with 107.615 square meters.

Landscape design of Büyükpark sustains visual access and visibility throughout the park. The trees are tall and the park is small enough to enable visual and physical access both between different areas of the park and the surrounding neighborhood. The park does not have any high shrubs that form hiding places. The ratio of wooded areas of Hasanağa Park is higher than Büyükpark. Green density and long shrubberies constitute some hiding points that prevent visual transparency in Hasanağa Park when compared with Büyükpark (Figure 5). 
Figure 1. Layout plan of Büyükpark

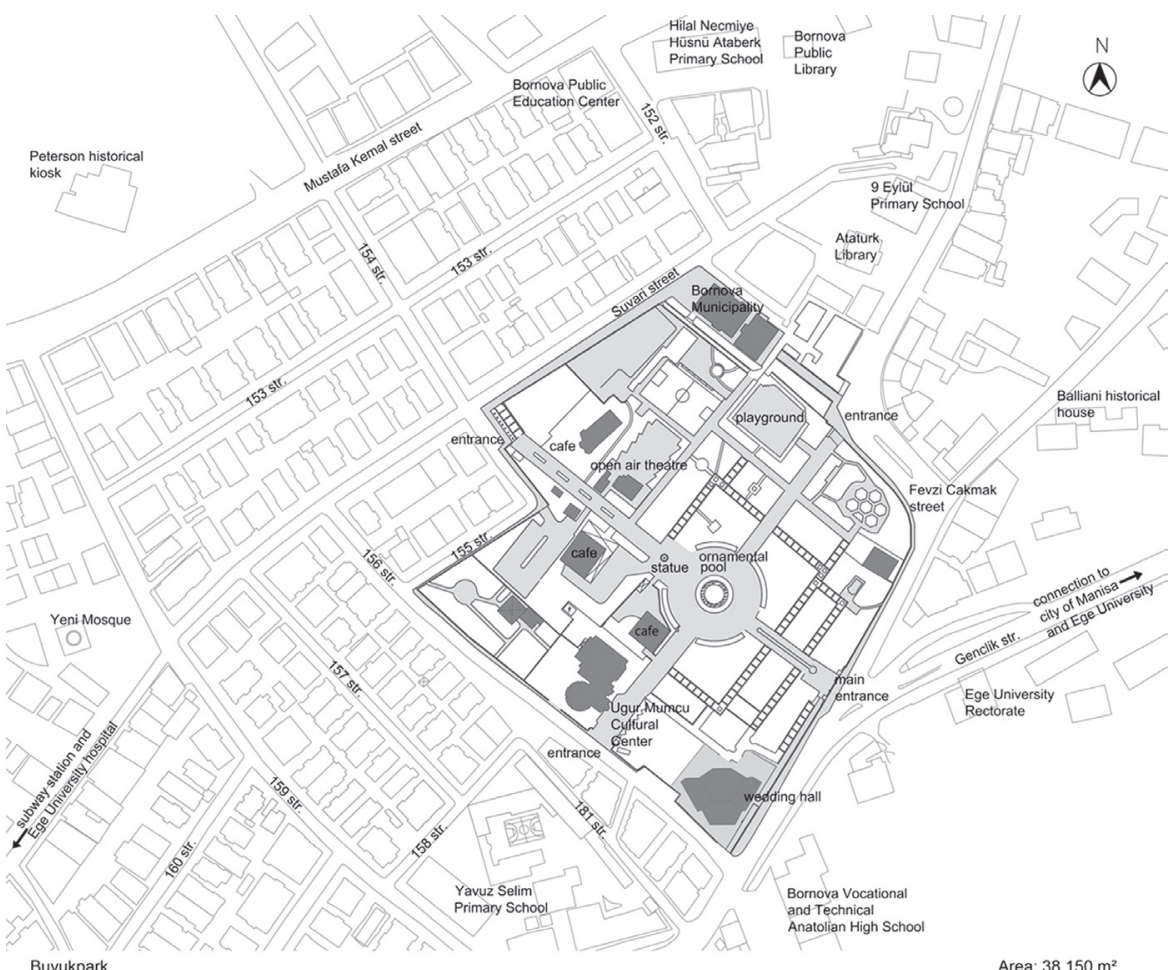

Figure 2. Layout plan of Hasanağa Park

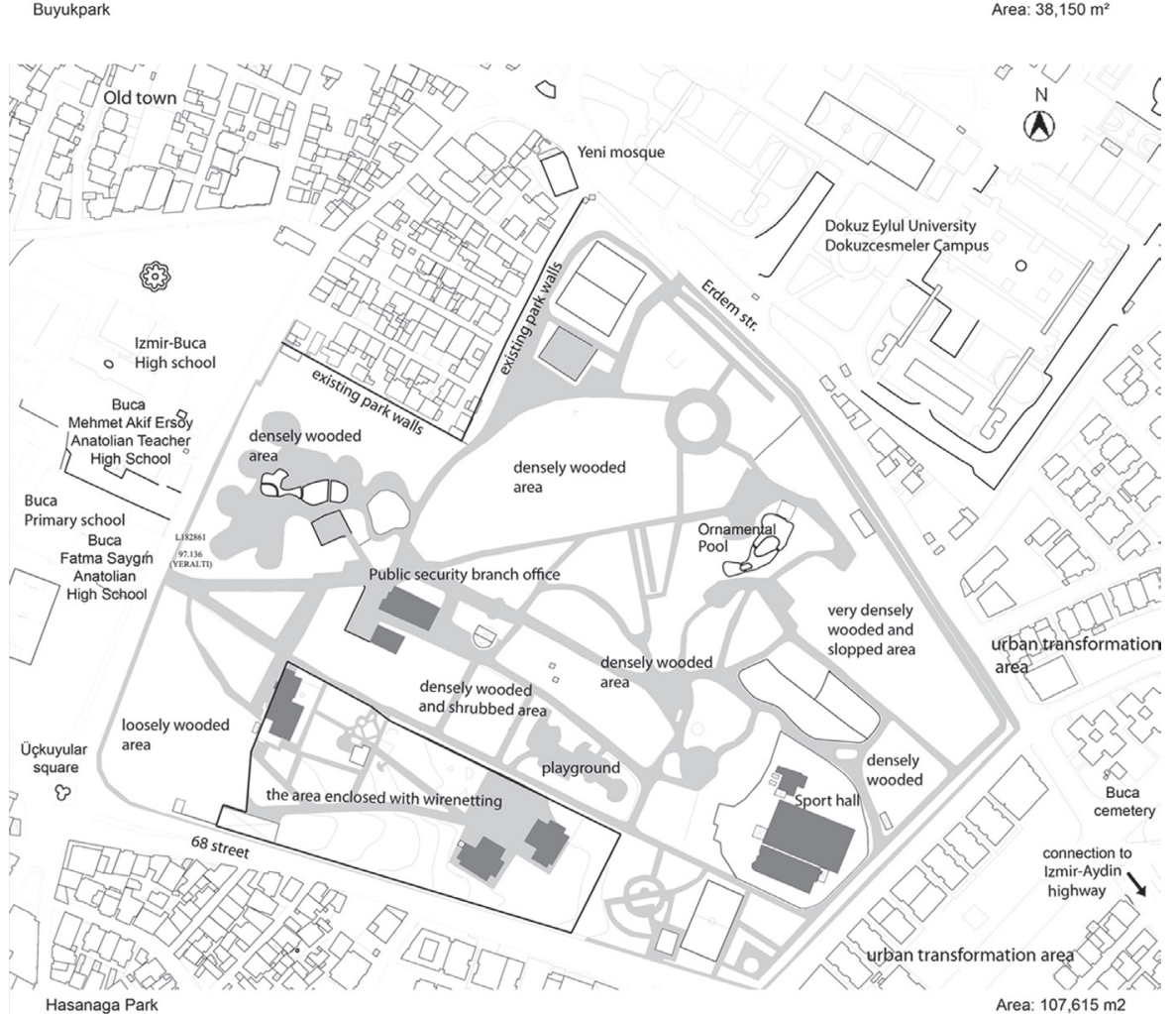

Maintenance, Activities, Lighting and Security Precautions

When Büyükpark can be considered as a manicured and a well-maintained park regarding its urban furniture, ornamental pool, cafes and green areas, Hasanağa Park can be evaluated as an unmaintained park. There is no surface greenery in some places of Hasanağa Park, quality and quantity of 
Figure 3. Views of landmarks in the parks

Figure 4. Views of the main entrances of the parks

Figure 5. Landscape designs of the parks
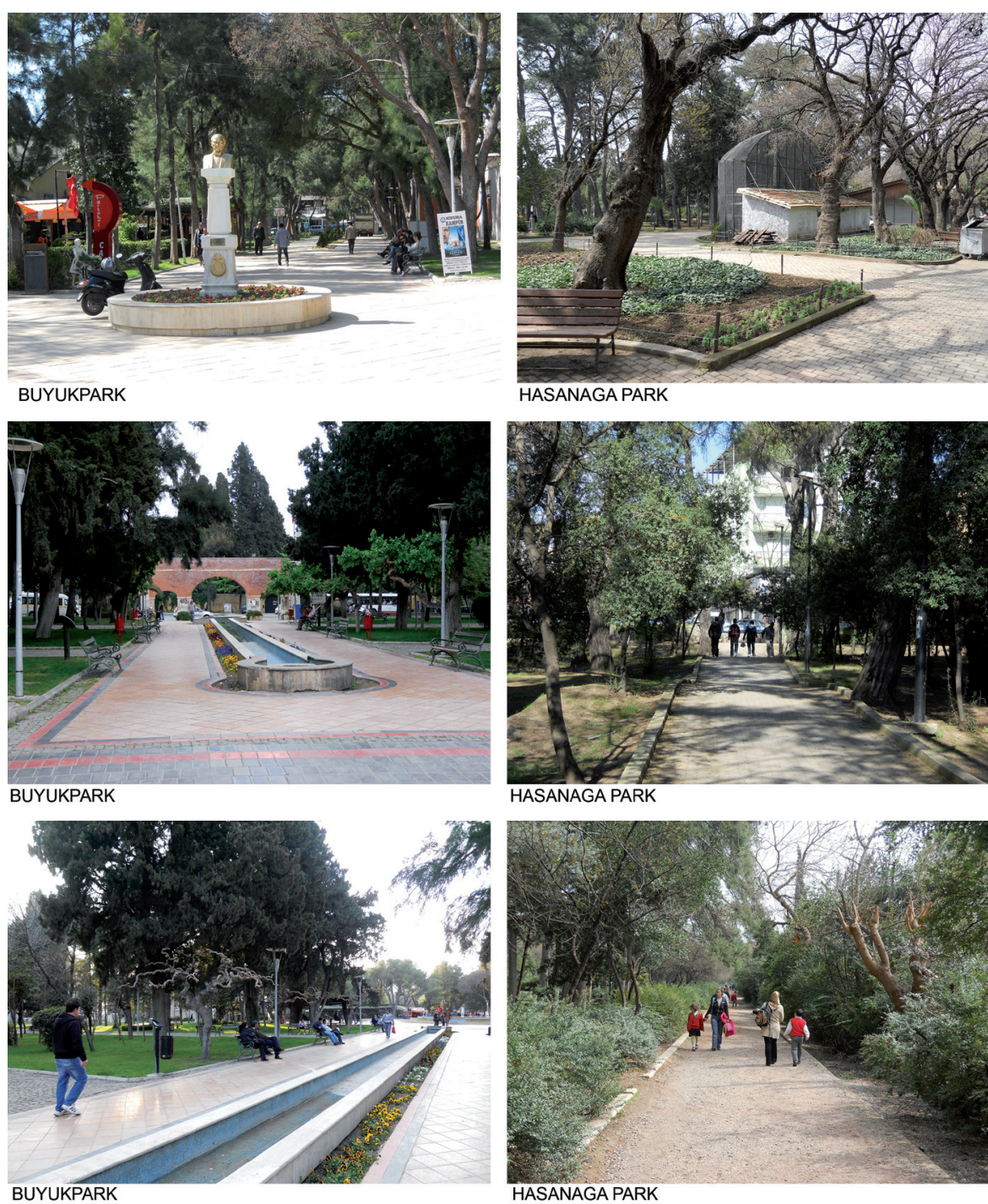

HASANAGA PARK

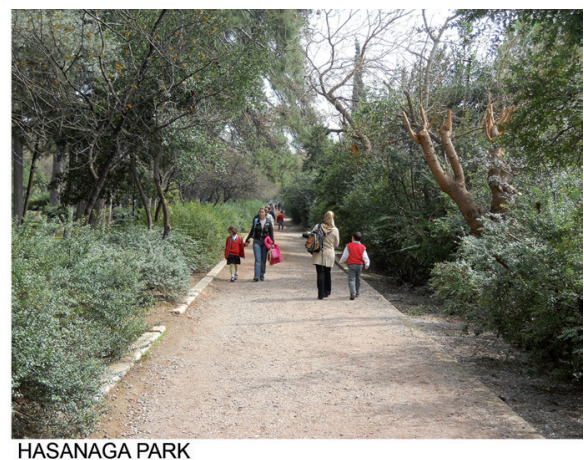

urban furniture is insufficient and the walls of the football playing area are covered with graffiti (Figure 6, Figure 7, Figure 8). Büyükpark offers three cafes, a cultural center, an open-air theatre, a wedding hall, a playground, a mini football playing area and a refreshment area with an ornamental pool at the centre. However, Hasanağa Park offers limited activities inside; a sports hall, a mini basketball and a football court, some walking and bicycle routes for sportive activities, refreshment area with an organically shaped but unmaintained ornamental pool, a playground for children and picnic facilities especially at weekends (Figure 9).

Unlike the Hasanağa Park, Büyükpark has good lighting and visibility during the night. Büyükpark does not have any security staff but Hasanağa Park has a public security branch office, which may affect user's sense of safety. There is no CCTVs for security and no "you are here" maps for ease of wayfinding in both parks. None of the parks have any rule signs, which prevent baggers, drug users, homeless people from using the parks. The only available signs in the parks indicate not to enter into the ornamental pool and not to use motorcycles in Büyükpark and not to make any fire in Hasanağa Park. 
Figure 6. Maintenance of urban furniture in the parks

Figure 7. Ornamental pools in the parks

Figure 8. Views of sports areas in the parks

Figure 9. Refreshment activities in the parks

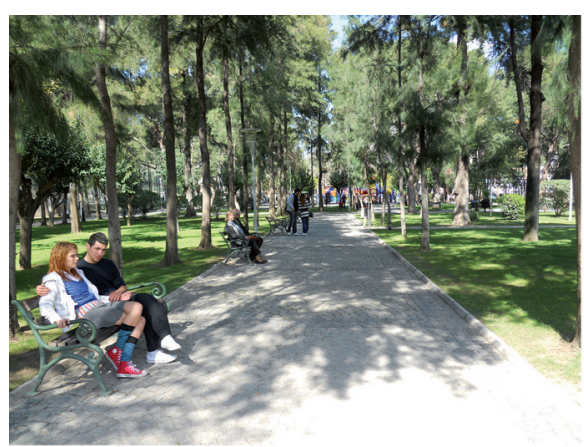

BUYUKPARK

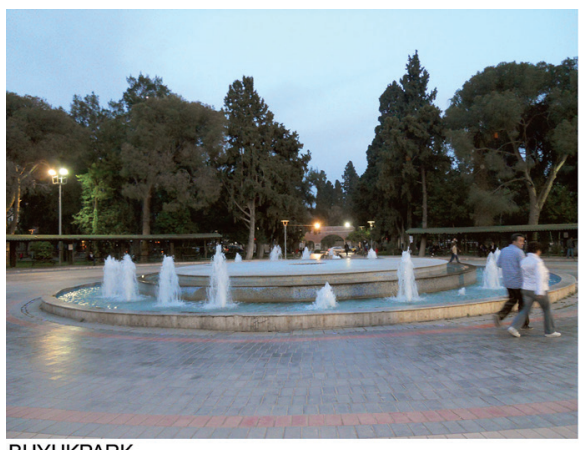

BUYUKPARK

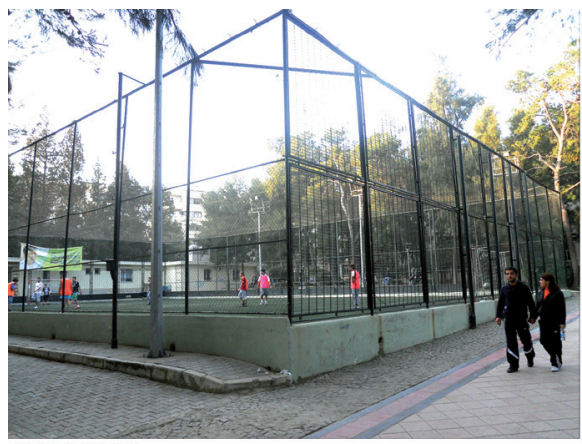

BUYUKPARK

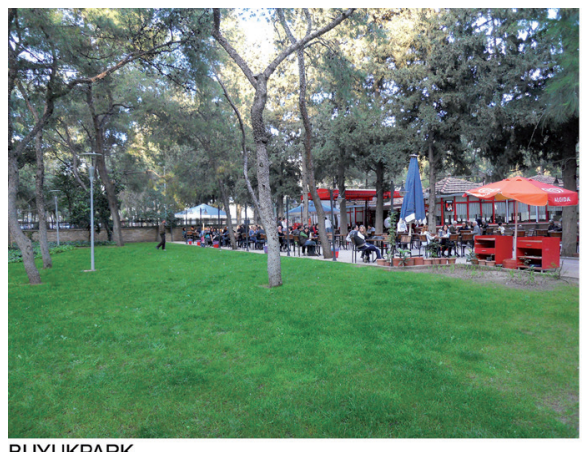

BUYUKPARK

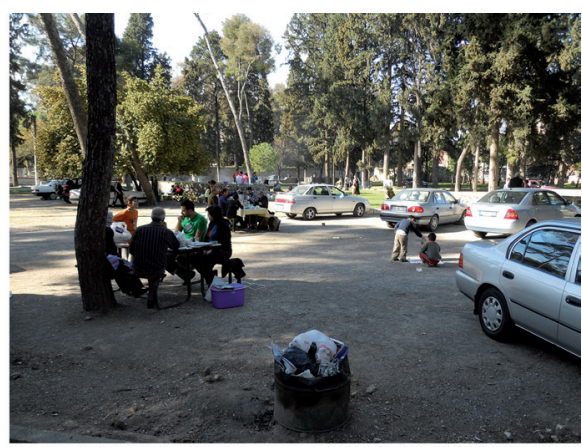

HASANAGA PARK

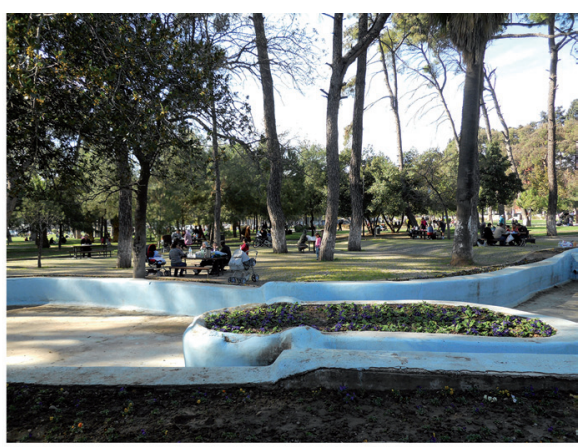

HASANAGA PARK

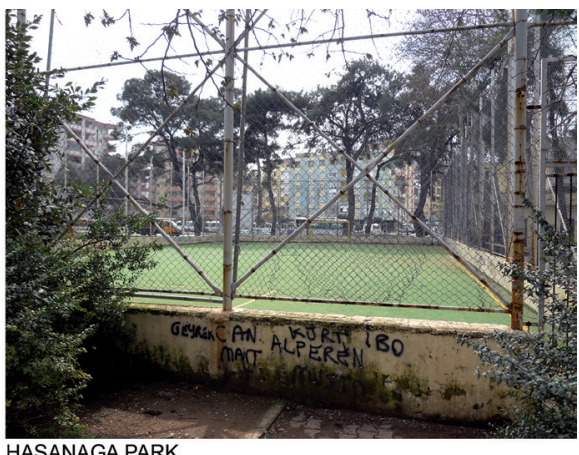

HASANAGA PARK

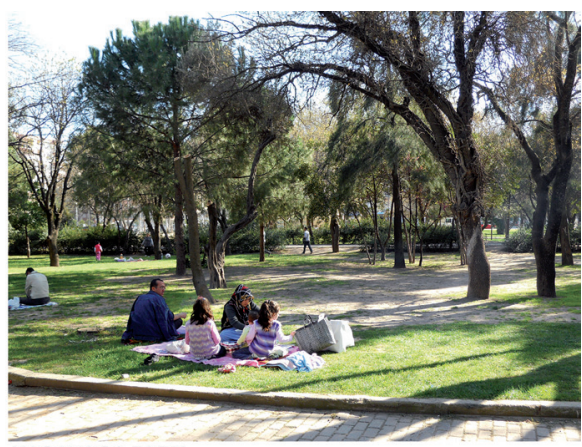

HASANAGA PARK

\section{Instrumentation and Procedure}

The field study have been conducted in both parks with a face-to-face questionnaire and participants were asked to answer closed ended questions. Data gathering has been performed by both authors of the study and eight undergraduate architecture students, who were trained before the application of the field study. Each interview has taken approximately 20 minutes. 683 randomly selected visitors, excluding younger groups 
less than 15 years old were asked to participate in the survey in different public open areas of the parks. Totally 442 visitors, 220 from Büyükpark and 222 from Hasanağa Park participated to the survey. Response level of the survey was $65 \%$ in total. Socio-demographic profiles of users were determined by the questions evaluating gender, age, marital status, education level and income. Participants were asked with whom they mostly visit, how frequently they visit, how much time they spend during their visits and at what time they mostly visit the examined parks in order to measure their park use.

Environmental design, demographic factors and park use have been independent and perceived safety has been dependent variables of our study. The effect of familiarity has been controlled by sampling familiar park users, who somehow use and know the environmental properties of the parks. The authors have developed a 13 item, 5 point Likert type scale to measure perceived safety of park users, based on the literature review presented in Section 2. The items related to environmental design (trees obstructing the view, hiding places), crowding (existence of unsafe people), wayfinding anxiety (describing a meeting point, finding the way easily), and environmental satisfaction (recommending the park, enjoying the park, feeling safe at park) have been included in the scale. Some unruly behaviors such as robbery, theft, sexual harassment and using park during the night have also been included in the scale as the items related to fear of crime. The responses have been taken by 5-point Likert type scale ranging from "completely agree" to "completely disagree". The scale has been organized as the higher mean value means higher perceived safety rating. The specialists in the Department of Social Psychology at Aegean University have been consulted to check the developed scale before the application. A pilot study has been conducted and some items of the scale have been revised before the main application. Reliability analysis has revealed that our scale is highly reliable (alpha coefficient: 0.83 ).

\section{RESULTS}

\section{Socio Demographic Profile of Park Users}

The socio-demographic profile of the two examined parks was comparatively analyzed with chi-square tests regarding gender, age, marital status, education and income. Although their urban locations were different, users of the two parks displayed similar properties regarding gender, marital status and income level. The users of the parks were different according to age $(\mathrm{p}<0.01)$ and education $(\mathrm{p}<0.01)$ variables. Although the ratio of middle aged (25-44) and young people (15-24) in Büyükpark was distributed almost equally (32.7\%; 32.3\% respectively), Hasanağa Park was mostly used by the young (45.9\%). Elderly people constituted the minority in both parks. Education levels of Büyükpark users were higher than the users of Hasanağa Park. The ratio of park users who graduated from high school and university in Büyükpark was higher (25.5\%; 32.3\% respectively) than Hasanağa Park users (18.5\% and $17.6 \%$ respectively).

\section{Frequencies of Park use}

Chi-square tests showed that majority of the users preferred visiting the parks either with their friends or with family members as commonly seen in Turkish society. However, the majority who visited the parks alone were Büyükpark users $(58 \%, \mathrm{p}<0.05)$. The most preferred visiting time 


\begin{tabular}{|c|c|c|c|c|c|c|}
\hline \multirow[b]{2}{*}{ Parks } & \multicolumn{3}{|c|}{ Frequency of park visits } & \multicolumn{3}{|c|}{ Duration of stay } \\
\hline & everyday & $\begin{array}{c}\text { once or } \\
\text { twice a week }\end{array}$ & $\begin{array}{c}\text { once or twice } \\
\text { a month or less }\end{array}$ & $\begin{array}{l}\text { less than } \\
\text { an hour }\end{array}$ & 1-2 hours & $\begin{array}{l}\text { 3-4 hours } \\
\text { and more }\end{array}$ \\
\hline \multicolumn{7}{|l|}{ Buyukpark (N: 220) } \\
\hline $\begin{array}{c}\mathrm{N} \\
\mathrm{N}(\%) \\
\end{array}$ & $\begin{array}{c}45 \\
20,5 \% \\
\end{array}$ & $\begin{array}{c}107 \\
48,6 \% \\
\end{array}$ & $\begin{array}{c}68 \\
30,9 \% \\
\end{array}$ & $\begin{array}{c}68 \\
30,9 \% \\
\end{array}$ & $\begin{array}{c}107 \\
48,6 \% \\
\end{array}$ & $\begin{array}{c}45 \\
20,5 \% \\
\end{array}$ \\
\hline \multicolumn{7}{|l|}{ Hasanaga Park (N:222) } \\
\hline $\begin{array}{c}\mathrm{N} \\
\mathrm{N}(\%) \\
\end{array}$ & $\begin{array}{c}36 \\
16,2 \% \\
\end{array}$ & $\begin{array}{c}90 \\
40,5 \% \\
\end{array}$ & $\begin{array}{c}96 \\
43,2 \% \\
\end{array}$ & $\begin{array}{c}49 \\
22,1 \% \\
\end{array}$ & $\begin{array}{c}88 \\
39,6 \% \\
\end{array}$ & $\begin{array}{c}85 \\
38,3 \% \\
\end{array}$ \\
\hline $\begin{array}{c}\mathrm{x} 2 \\
* \mathrm{p}<0,05 ; * * \mathrm{p}<0,01\end{array}$ & & $\begin{array}{c}7,239 \\
\mathbf{0 , 0 2 7 *}\end{array}$ & & & $\begin{array}{l}17,236 \\
\mathbf{0 , 0 0 0}^{* *}\end{array}$ & \\
\hline
\end{tabular}

was afternoon in both Büyükpark and Hasanağa Park (\%45.2 and \%40.5 respectively). Besides, night time was the least preferred time by users of both Büyükpark and Hasanağa Park (\%8.2 and 4.1\% respectively) and the majority who visited the parks during the night time was Büyükpark users $(67 \%, p<0.01)$. Gender and age were significant variables for park use in Hasanağa Park ( $<<0.05$ and $p<0.01$ respectively) but not in Büyükpark. All night time users were male and most of them were young and middle aged people ranging in between 15-44 (88\%) in Hasanağa Park.

Analyses showed a significant difference between two parks regarding frequency of park visits $(\mathrm{p}<0.05)$. The results indicated that Büyükpark was being more frequently used than Hasanağa Park. The ratio of every day visitors and the ones, who visited the parks once or twice a week, were higher in Büyükpark (20.5\%; $48.6 \%$ respectively) than in Hasanağa Park (16.6\% and $40.5 \%$ respectively). Duration of stay was also statistically significant between two parks $(\mathrm{p}<0.00)$. However, visitors spent less time in Büyükpark during their park visits (less than an hour; $30.9 \%$ and about 1-2 hours; $48.6 \%$ ) than visitors of Hasanağa Park (22.1\%; 39.6\% respectively). The results demonstrated that users visited Büyükpark more frequently but spent less time there than users of Hasanağa Park (Table 1).

\section{Comparisons Regarding Perceived Safety}

Dimensions of Perceived Safety

Factor analysis with varimax rotation was applied to the responses given to scale to determine underlying dimensions of perceived safety. This analysis was also used as a tool to assess the relations among different dimensions of perceived safety and independent variables of the study. The analysis revealed three factors; the first factor which was named as "perceived safety from crime" consisted of the items that measure the feeling against potential offenders such as; sexual harassment, unnatural behaviors, criminal activities like robbery and theft, night use and being alone in the parks. This was the most important factor explaining $23.15 \%$ of the total variance. The second factor, which was named as "environmental satisfaction" explaining $17.08 \%$ of total variance, consisted of the items such as; recommending the park to another person, enjoying being in the park and feeling safe in the park. The third factor, which was named as "visual access and wayfinding" and explained $16.16 \%$ of total variance, consisted of the items including hiding places, tree density, ease of wayfinding and ease of describing a meeting point (Table 2).

The Relation between Environmental Design and Perceived Safety

Environmental variables of the study were represented with park types, as explained in Section 3. Man Whitney U and Kruskal Wallis tests were applied to the data to see the comperative relations between perceived 


\begin{tabular}{|c|c|c|c|c|}
\hline Factors & Items & $\begin{array}{l}\text { Factor } \\
\text { Loading }\end{array}$ & $\mathbf{E}$ & $\%$ \\
\hline & I am annoyed by the fact that unsafe people are wondering around* & 0,767 & 3,009 & 23,15 \\
\hline (Factor I) & It is possible to experience sexual harrasment in this park ${ }^{* *}$ & 0,735 & & \\
\hline Perceived safety & Some disturbing circumstances can happen in this park ${ }^{* *}$ & 0,689 & & \\
\hline \multirow[t]{3}{*}{ from crime } & Robbery and theft is unusual in this park** & 0,644 & & \\
\hline & I can visit this park during the night without any hesitation** & 0,516 & & \\
\hline & I feel safer when the park is crowded ${ }^{* *}$ & 0,455 & & \\
\hline (Factor II) & I recommend this park to the others** & 0,839 & 2,22 & 17,08 \\
\hline Environmental & I enjoy being here** & 0,815 & & \\
\hline satisfaction & I feel safe in this park** & 0,583 & & \\
\hline (Factor III) & $\begin{array}{l}\text { I am nervous about the fact that trees obstruct my view } \\
\text { in some places of the park** }\end{array}$ & 0,747 & 2,1 & 16,15 \\
\hline \multirow[t]{3}{*}{$\begin{array}{l}\text { Visual access and } \\
\text { wayfinding }\end{array}$} & $\begin{array}{l}\text { It is not easy to describe a meeting point to a person } \\
\text { who is not familiar with this park** }\end{array}$ & 0,663 & & \\
\hline & I can find my way easily in this park** & 0,62 & & \\
\hline & Some hiding places disturb me in this park** & 0,603 & & \\
\hline
\end{tabular}

Table 2. Factor analysis of perceived safety

Table 3. Analysis of perceived safety regarding park types safety and variables of the study. The results displayed that perceived safety levels of the two parks' users were significantly different from each other. Büyükpark users felt themselves safer in terms of fear of crime $(p<0.01)$, were more satisfied with their parks $(p<0.01)$, and sustained their visual access and wayfinding more than the users of Hasanağa Park $(\mathrm{p}<0.01)$ (Table 3) (Figure 10).

The Relation between Demographic Factors and Perceived Safety

According to results of this study, not income but gender, age, marital status and education were significant socio-demographic variables in relation to perceived safety. The results confirmed that gender was important parameter only for perceived safety from crime but not for environmental satisfaction and visual access and wayfinding. Women felt themselves less safe than men because of fear of crime in both parks $(p<0.01)$ (Table 4). The age was significant for perceived safety from crime in both Büyükpark $(\mathrm{p}<0.05)$ and Hasanağa Park $(\mathrm{p}<0.01)$. Young people between 15 and 24 years old felt themselves less safe than elderly people over 65 years old. Additionally, the age was also a significant variable for "Environmental satisfaction" factor in Hasanağa Park but not in Bornova Park. Young people ranging from 15-24 years old were less satisfied than elderly people only in Hasanağa Park probably due to inadequate park activities. Interestingly, elderly people felt themselves more capable in terms of visual access and wayfinding, when compared to the young

\begin{tabular}{|c|c|c|c|c|c|}
\hline Park type & $\mathrm{N}$ & $\begin{array}{l}\text { Perceived safety } \\
\text { from crime }(\mathrm{M})\end{array}$ & $\begin{array}{l}\text { Environmental } \\
\text { satisfaction }(\mathrm{M})\end{array}$ & $\begin{array}{l}\text { Visual access and } \\
\text { wayfinding }(\mathrm{M})\end{array}$ & $\begin{array}{l}\text { Total } \\
(\mathrm{M}) \\
\end{array}$ \\
\hline Buyukpark & 220 & 2,75 & 4,07 & 3,98 & 3,43 \\
\hline Hasanaga Park & 222 & 2,24 & 3,62 & 3,00 & 2,79 \\
\hline $\mathrm{p}<0,05 ; * * \mathrm{p}<0,01$ & & $0,000 * *$ & $0,000 * *$ & $0,000 * *$ & $0,000 * *$ \\
\hline
\end{tabular}




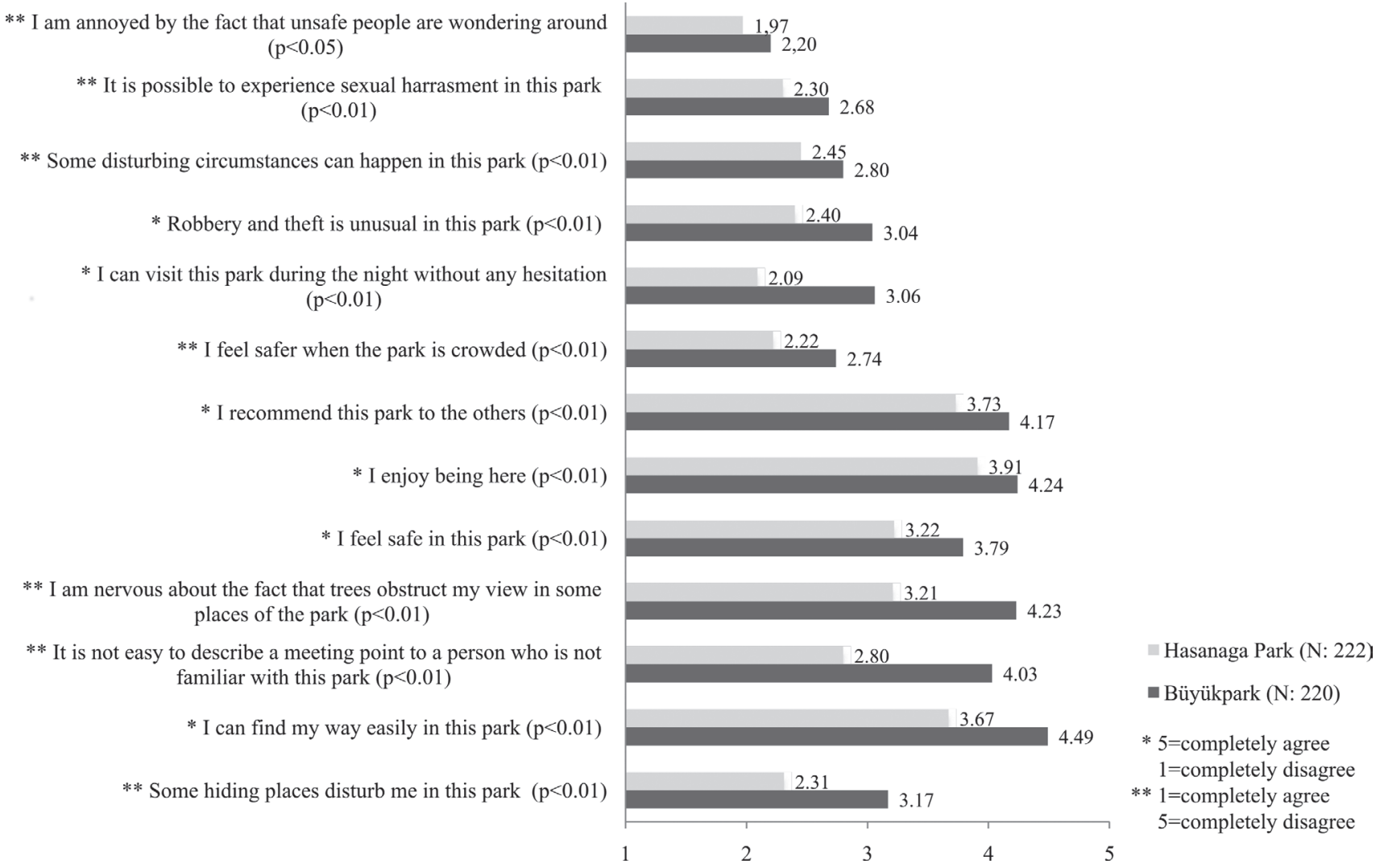

Figure 10. Comparison of the responses given to the items of perceived safety scale in two parks $(p<0.01)$ (Table 5). Significant results were obtained for education variable only in Hasanağa Park. People with higher education level felt themselves less safe from crime $(\mathrm{p}<0.01)$ and less satisfied than less educated ones $(p<0.01)$ (Table 6). Marital status was also a significant variable for perceived safety. Married people felt themselves safer from fear of crime than single people in both Büyükpark $(p<0.05)$ and Hasanağa Park $(p<0.01)$. Besides, married people felt more satisfied $(p<0.01)$ and more capable for visual access and wayfinding only in Hasanağa Park $(p<0.01)$ (Table 7).

\section{The Relation between Park Use and Perceived Safety}

Visiting frequency was found as a significant variable for perceived safety. The results have displayed that the most frequent visitors felt themselves safer from crime in Hasanağa Park than the least frequent visitors $(p<0.05)$. Besides, the most frequent users were more satisfied $(\mathrm{p}<0.05)$ and more capable in wayfinding when compared to the infrequent ones in both parks $(p<0.05)$. Duration of stay was also significantly associated with perceived safety only for the factor of environmental satisfaction in Büyükpark $(\mathrm{p}<0.01)$ and for all three dimensions of perceived safety in Hasanağa Park $(\mathrm{p}<0.01)$ (Table 8).

\begin{tabular}{|c|c|c|c|c|c|c|}
\hline Parks & Gender & $\mathrm{N}$ & $\begin{array}{l}\text { Perceived safety } \\
\text { from crime (M) }\end{array}$ & $\begin{array}{l}\text { Environmental } \\
\text { satisfaction (M) }\end{array}$ & $\begin{array}{l}\text { Visual access and } \\
\text { wayfinding (M) }\end{array}$ & $\begin{array}{l}\text { Total } \\
(\mathrm{M})\end{array}$ \\
\hline \multirow{3}{*}{ Buyukpark } & Woman & 93 & 2,56 & 3,99 & 3,91 & 3,31 \\
\hline & Man & 127 & 2,89 & 4,13 & 4,03 & 3,53 \\
\hline & Total N & 220 & & & & \\
\hline \multicolumn{3}{|l|}{$* \mathrm{p}<0,05 ; * * \mathrm{p}<0,01$} & $0,001^{* *}$ & 0,05 & 0,31 & $0,001^{* *}$ \\
\hline \multirow{3}{*}{ Hasanaga Park } & Woman & 94 & 2,09 & 3,56 & 2,97 & 2,70 \\
\hline & Man & 128 & 2,35 & 3,66 & 3,02 & 2,86 \\
\hline & Total N & 222 & & & & \\
\hline
\end{tabular}


Table 5. Analysis of perceived safety regarding age

Table 6. Analysis of perceived safety regarding education level

Table 7. Analysis of perceived safety regarding marital status

Table 8. Analysis of perceived safety regarding park use

\begin{tabular}{|c|c|c|c|c|c|c|}
\hline Parks & Age & $\mathrm{N}$ & $\begin{array}{r}\text { Perceived safety } \\
\text { from crime (M) } \\
\end{array}$ & $\begin{array}{l}\text { Environmental } \\
\text { satisfaction }(\mathrm{M}) \\
\end{array}$ & $\begin{array}{l}\text { Visual access and } \\
\text { wayfinding (M) }\end{array}$ & $\begin{array}{c}\text { Total } \\
(\mathrm{M}) \\
\end{array}$ \\
\hline \multirow{5}{*}{ Buyukpark } & $15-24$ & 71 & 2,64 & 4,00 & 3,92 & 3,35 \\
\hline & $25-44$ & 72 & 2,78 & 4,11 & 4,08 & 3,49 \\
\hline & $45-65$ & 54 & 2,70 & 4,12 & 3,96 & 3,42 \\
\hline & 65 and over & 23 & 3,12 & 4,03 & 3,91 & 3,58 \\
\hline & Total N & 220 & & & & \\
\hline \multicolumn{3}{|l|}{$* \mathrm{p}<0,05 ; * * \mathrm{p}<0,01$} & $0,022 \%$ & 0,76 & 0,73 & 0,10 \\
\hline \multirow{5}{*}{ Hasanaga Park } & $15-24$ & 102 & 2,04 & 3,24 & 2,79 & 2,55 \\
\hline & $25-44$ & 68 & 2,37 & 3,85 & 3,10 & 2,93 \\
\hline & $45-65$ & 44 & 2,34 & 3,99 & 3,25 & 3,00 \\
\hline & 65 and over & 8 & 3,06 & 4,50 & 3,47 & 3,52 \\
\hline & Total N & 222 & & & & \\
\hline
\end{tabular}

\begin{tabular}{|c|c|c|c|c|c|c|}
\hline Parks & Education & $\mathrm{N}$ & $\begin{array}{l}\text { Perceived safety } \\
\text { from crime }(\mathrm{M})\end{array}$ & $\begin{array}{l}\text { Environmental } \\
\text { satisfaction }(\mathrm{M})\end{array}$ & $\begin{array}{l}\text { Visual access and } \\
\text { wayfinding }(\mathrm{M})\end{array}$ & $\begin{array}{l}\text { Total } \\
\text { (M) }\end{array}$ \\
\hline \multirow{4}{*}{ Buyukpark } & Primary education & 58 & 2,72 & 4,15 & 3,91 & 3,59 \\
\hline & High school & 71 & 2,69 & 4,10 & 4,01 & 3,60 \\
\hline & University/Msc/Ph.D & 91 & 2,83 & 3,99 & 4,01 & 3,61 \\
\hline & Total N & 220 & & & & \\
\hline \multicolumn{3}{|l|}{$* \mathrm{p}<0,05 ; * * \mathrm{p}<0,01$} & 0,55 & 0,23 & 0,72 & 0,85 \\
\hline \multirow{4}{*}{ Hasanaga Park } & Primary education & 46 & 2,48 & 4,07 & 3,14 & 3,23 \\
\hline & High school & 39 & 2,46 & 3,84 & 3,14 & 3,15 \\
\hline & University/Msc/Ph.D & 136 & 2,10 & 3,40 & 2,90 & 2,80 \\
\hline & Total N & 222 & & & & \\
\hline
\end{tabular}

\begin{tabular}{|c|c|c|c|c|c|c|}
\hline Parks & Marital status & $\mathrm{N}$ & $\begin{array}{l}\text { Perceived safety } \\
\text { from crime (M) }\end{array}$ & $\begin{array}{l}\text { Environmental } \\
\text { satisfaction (M) }\end{array}$ & $\begin{array}{l}\text { Visual access and } \\
\text { wayfinding }(\mathrm{M})\end{array}$ & $\begin{array}{c}\text { Total } \\
\text { (M) }\end{array}$ \\
\hline \multirow{4}{*}{ Buyukpark } & Married & 112 & 2,85 & 4,11 & 3,99 & 3,49 \\
\hline & Single & 96 & 2,66 & 4,00 & 3,97 & 3,37 \\
\hline & Divorced/widow & 12 & 2,54 & 4,22 & 3,96 & 3,37 \\
\hline & Total N & 220 & & & & \\
\hline \multicolumn{3}{|l|}{$* \mathrm{p}<0,05 ; * * \mathrm{p}<0,01$} & $0,026^{*}$ & 0,27 & 0,82 & 0,08 \\
\hline \multirow{4}{*}{ Hasanaga Park } & Married & 94 & 2,42 & 3,95 & 3,12 & 2,99 \\
\hline & Single & 118 & 2,06 & 3,31 & 2,88 & 2,60 \\
\hline & Divorced/widow & 10 & 2,70 & 4,17 & 3,23 & 3,20 \\
\hline & Total N & 222 & & & & \\
\hline
\end{tabular}

\begin{tabular}{|c|c|c|c|c|c|c|}
\hline Parks & Frequency of park visit & $\mathrm{N}$ & $\begin{array}{l}\text { Perceived safety } \\
\text { from crime }(\mathrm{M})\end{array}$ & $\begin{array}{l}\text { Environmental } \\
\text { satisfaction (M) }\end{array}$ & $\begin{array}{l}\text { Visual access and } \\
\text { wayfinding }(\mathrm{M})\end{array}$ & $\begin{array}{c}\text { Total } \\
(\mathrm{M})\end{array}$ \\
\hline \multirow{4}{*}{ Buyukpark } & every day & 45 & 2,807 & 4,185 & 3,844 & 3,612 \\
\hline & once or twice a week & 107 & 2,763 & 4,131 & 4,061 & 3,652 \\
\hline & once or twice a month & 68 & 2,699 & 3,892 & 3,945 & 3,512 \\
\hline & Total N & 220 & & & & \\
\hline \multicolumn{3}{|l|}{$* \mathrm{p}<0,05 ; * * \mathrm{p}<0,01$} & 0,852 & $0,014^{*}$ & 0,164 & 0,189 \\
\hline \multirow{4}{*}{ Hasanaga Park } & every day & 36 & 2,477 & 3,898 & 3,278 & 3,218 \\
\hline & once or twice a week & 90 & 2,3093 & 3,6333 & 2,9528 & 2,9651 \\
\hline & once or twice a month & 96 & 2,082 & 3,500 & 2,935 & 2,839 \\
\hline & Total N & 222 & & & & \\
\hline
\end{tabular}

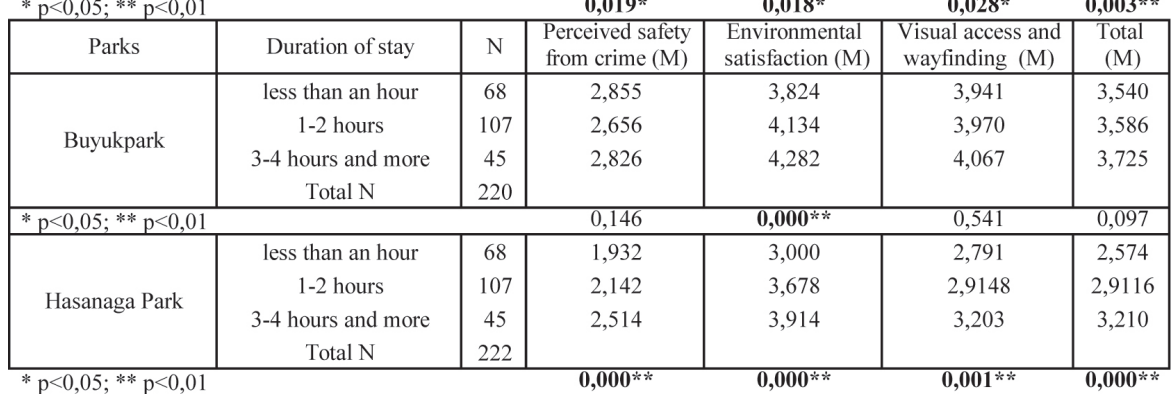




\section{DISCUSSION AND CONCLUSION}

This study contributes to existing literature with an on-site research on perceived safety in urban parks of İzmir, Turkey. In the study, environmental, demographic and perceptual factors have been utilized to explain perceived safety in urban parks. Research results that display the profound importance of "fear of crime" on perceived safety in urban parks are in line with findings of previous research (Wekerle and Whitzman, 1994; King et al., 2000; Zakarian et al., 1994). However, this study has enhanced the meaning of perceived safety by indicating the significance of wayfinding anxiety and environmental satisfaction for sense of safety in urban parks. The results also supported statistically the statement of Lawton and Kallai's study (2002) that stresses the relation between wayfinding and safety perception with a cross cultural study. Further research may investigate safety problems of urban parks with a broader sense beyond fear of crime.

In consistency with previous environmental studies (Fisher and Nasar, 1992; Schroeder and Anderson, 1984; Westover, 1986) environmental design appeared as an important parameter for sense of safety in parks in this research. In İzmir case, findings obtained from Büyükpark demonstrated that users of the park have more perceived safety from crime, more wayfinding ability and more environmental satisfaction than users of Hasanağa Park. Diverse characteristics of Büyükpark such as; having central urban location, vivid activities inboth surrounding neighborhood and the parks, smaller size, well-manicured and maintained environment and landscape design, which does not include any buffer zones, fences or hiding places for ease of visual and physical access, decrease users' fear of crime. Besides, good maintenance, sufficient urban furniture, and ongoing social, cultural and recreational activities that contribute Büyükpark to live during the day and the night may have decreased both fear of crime and enhanced environmental satisfaction and overall perceived safety of users. The higher wayfinding ability of Büyükpark users contributing to overall perceived safety may be explained with Büyükpark's small size, legible planning, landscape design and landmarks that enable visual access and enhance cognitive image of the park (Lynch, 1960; Weisman 1987).

Furthermore, the analysis in this paper demonstrated that demographic factors such as, gender, age, education level and marital statue of people have a strong impact on sense of safety. Women have more fear of crime than men as also highlighted in previous research (Westover (1985).

This result can be explained by women's fear of assault because of their physical weaknesses that may cause a lower sense of safety in case of an attack. When age factor is considered, in contrast to findings of many other studies (Ferraro and La Grange, 1987; Godbey and Blazey, 1983; Ortega and Myles, 1987), this study shows similarity with Mc Coy et al.'s findings (1996) that demonstrated age is an important factor to enhance perceived safety. However, this finding should be interpreted with limitations of this research. The number of elderly participants, who constitute the minority in both parks, is considerably low, when compared to the total number of the participants. Besides, most of elderly people are from Büyükpark, which has affirmative environmental qualities in terms of safety. The results should be evaluated with these limitations.

Education level is another significant factor related to both fear of crime and environmental satisfaction in Hasanağa Park but not in Büyükpark. The results indicate that less educated people feel safer and are more 
satisfied when compared to people with higher education level. However, this finding is not consistent with previous research (Scarborough et al., 2010). It should be stressed that most of the participants with higher education level are from Hasanağa Park, due to the presence of Dokuz Eylul University Campus located just across this park. This contextual factor might have an impact on research results, since Hasanağa users had lower sense of safety. Therefore, effect of education variable on perceived safety needs further analysis.

Marital status is found as another significant factor on perceived safety in both case study parks. Married people usually feel safer than singles. Crowding factor, which is a significant factor in our perceived safety scale, may explain the result. Since married people are the ones who generally visit the parks with their families and friends as commonly seen in our society, they might feel safer.

There is a strong relation between perceived safety and park use. Büyükpark, which is perceived safer by park users, has been more frequently used than Hasanağa Park. This finding is consistent with recent studies arguing that safer parks are more frequently used than less safe ones (Van Herzele and Wiedemann, 2003; Marcus and Francis, 1998, Schroeder and Anderson, 1984). Büyükpark, which offers more cultural, recreational and social activities than Hasanağa Park, has more effectively been used for multi purposes even in the night time. Majority of people visiting the parks alone are from Büyükpark. This finding also indicates that being alone is less stressful in safe parks such as Büyükpark.

Time spent during park visits, which is another criterion to evaluate park use in this study, should be suspiciously considered as a measure of perceived safety or user attachment without regarding the ongoing activities in the parks. Users of Hasanaga Park less frequently visited the park but spent more time during their visits although sense of safety in Hasanağa Park is lower than Buyukpark. Since Hasanağa Park is used especially for activities like sports and picnic during weekends, users of Hasanağa Park may spend more time than users of Büyükpark because of these long lasting activities, not because of their senses of safety.

It is important to have security precautions, like CCTV and security staff especially for women, elderly and handicapped people in urban parks since these precautions may enhance sense of safety in urban parks. However, in this study, although Hasanağa Park has a public security branch office inside, Büyükpark has been perceived safer than the other. The result displayed that security precautions are not sufficient alone to enhance sense of safety, when environmental properties and especially lighting of parks have been neglected, such as Hasanağa Park.

Our research has some limitations that should be considered in further studies. The suggested scale to measure perceived safety can be improved in further researches including the items considering familiarity, disabilities of people, properties of surrounding neighborhood, which either controlled or disregarded within the limitations of this study. Familiarity factor which may affect perceived safety was controlled in this study in a considerable extend to achieve the aims of the research. The field study was conducted in parks with park users by disregarding the ones living in the surrounding neighborhood. Because one of the aims of the study was to test many important findings of the previous experimental research in real park environments regarding users' "environmental 
experience". Besides, we could see the relationship between frequency of parks visits and perceived safety by disregarding unfamiliar park users. Children as participants and environmental properties of surrounding neighborhood have been neglected in this research. Only, nature of visual and physical access and the ongoing activities in the surrounding neighbourhood have been considered. Additionally, profile of residents and crime rates in the surrounding neighborhood have been disregarded in this research. Since all these uncontrolled variables may affect perceived safety in parks, further studies may consider these issues. In addition to considered demographics in this study, there are many individual factors that may affect people's sense of safety in the parks. These include, but not limited to, people's profession, physical abilities, inabilities, memories, past experiences and emotional solidarity, previous places of residences of park users and proximity of their residences to the parks.

One of the major strengths of this study is its sample size and comparative analysis method. Additionally, the results of the study have contributed to the related studies with that not only fear of crime but also environmental satisfaction and wayfinding are important dimensions to explain perceived safety. In this case, it is important to take not only design or security precautions that prevent fear of crime, but also to suggest environmental designs that may improve wayfinding ability and environmental satisfaction in urban parks. The correlations between environmental satisfaction, wayfinding and perceived safety can be explained deeply in further research with larger samples including children, familiar and unfamiliar residents in the surrounding neighborhood. This study should be accepted as a preliminary study that investigated and tested many important dimensions of perceived safety in real park environments especially in a different society introduced with urban parks after Modern Republican Period.

\section{ACKNOWLEDGEMENTS}

We would like to thank all the reviewers who carefully have reviewed our paper and contributed much for improvement of it. Additionally, we would like to thank Res. Asst. İlker Yalıner and Res. Asst. Fulya Selçuk for their help to revise the maps used in this study and also the undergraduate architecture students who helped to conduct the questionnaire on site.

\section{REFERENCES}

APPLETON, J. (1975) The Experience of Place, Wiley, London.

ATKINS S., HUSAIN S., STOREY A. (1991) The Influence of Street Lighting on Crime and Fear of Crime, Report no: 8, Crime Prevention Unit, London.

ATKINS S., HUSAIN S., STOREY A. (1991) The Influence of Street Lighting on Crime and Fear of Crime, Report no: 8, Crime Prevention Unit, London.

AUSTIN, D.M., FURR, L.A., SPINE, M. (2002) The Effects of Neighborhood Conditions on Perceptions of Safety, Journal of Criminal Justice (30) 417-27.

BABA Y., AUSTIN D.M. (1989) Neighborhood Environmental Satisfaction, Victimization, and Social Participation as Determinants of Perceived Neighborhood Safety, Environment and Behavior (21) 763-80. 
BEDIMO-RUNG A.L., MOWEN A.J., COHEN D.A. (2005) The Significance of Parks to Physical Activity and Public Health: A Conceptual Model, American Journal of Preventive Medicine (28) 159-68.

BIXLER R.D., FLOYD M.F. (1997) Nature is Scary, Disgusting, and Uncomfortable, Environment and Behaviour (29) 443-67.

COHEN D.A., GOLINELLI D., WILLIAMSON S., SEHGAL A., MARSH T., MCKENZIE T.L. (2009) Effects of Park Improvements on Park Use and Physical Activity Policy and Programming Implications, American Journal of Preventive Medicine (37) 475-80.

COHEN, S., EVANS, G.W., KRANTZ, D.S (1986) Behavior, Health and Environmental Stress, New York, Plenum.

CREWE K. (2001) Linear Parks and Urban Neighborhoods: A Study of the Crime Impact of the Boston South-west Corridor, Journal of Urban Design (6) 245-64.

FARRALL S., BANNISTER J., DITTON J., GILCHRIST E. (2000) Social Psychology and the Fear of Crime, British Journal of Criminology (40) 399-413.

FERRARO K., LA GRANGE R. (1987) The Measurement of Fear of crime, Sociological Inquiry (57) 70-101.

FISHER B.S., NASAR J.L. (1992) Fear of Crime in Relation to Three Exterior Site Features, Prospect, Refuge and Escape, Environment and Behavior (24) 35-65.

FORSTHY A., MUSACCIO L., FITZGERALD F. (2005) Designing Small Parks: A Manual Addressing Social and Ecological Concerns, Wiley, Hoboken.

GILL, M., SPRIGGS, A. (2005) Assessing the Impact of CCTV, Report no: 292, Home Office Research Study.[https://www.cctvusergroup.com/ downloads/file/Martin\%20gill.pdf] Access Date (15.11.2015).

GODBEY G., BLAZEY M. (1983) Old People in Urban Parks: An Exploratory Investigation, Journal of Leisure Research (15) 229-44.

GRAEFE A.R., ABSHER, J.D., BURNS, R.C. (2000) Monitoring Visitor Satisfaction: A Comparison of Comment Cards and More In-depth Survey, Proceedings of the 2000 Northeastern Recreation Research Symposium (April 2-4, 2000), New York, 265-9.

HALE C. (1996) Fear of Crime: A Review of the Literature, International Review of Victimology (4) 79-150.

HARDEN J. (2000) There's No Place Like Home: The Public/Private Distinction in Children's Theorizing Risk and Safety, Childhood (1) 43-59.

HERZOG T.R., CHERNICK K.K. (2000) Tranquility and Danger in Urban and Natural Settings, Journal of Environmental Psychology (20) 29-39.

HERZOG T.R., KAPLAN S., KAPLAN R. (1976) The Prediction of Preference for Familiar Urban Places, Environment and Behavior (8) $627-45$.

ISNARD, A. (2001). Can Surveillance Cameras be Successful in Preventing Crime and Controlling Antisocial Behaviors?, The Character, Impact 
and Prevention of Crime in Regional Australia Conference (1-3 August, 2001), Australian Institute of Criminology, Townsville, 1-19.

JORGENSEN A., HITCHMOUGH J., CALVERT T. (2002) Woodland Spaces and Edges: Their Impact on Perception of Safety and Preference, Landscape and Urban Planning (60) 135-50.

KAPLAN R. (1976) Wayfinding in the Natural Environment, Environmental Knowing: Theories, Research and Methods, eds. G.T. Moore, R.G. Golledge, Dowden Hutchinson and Rose, Stroudsburg; 46-57.

KING A.C., CASTRO C., WILCOX S., EYLER A.A., SALLIS J.F., BROWNSON R.C. (2000) Personal and Environmental Factors Associated with Physical Inactivity Among Different Racial-ethnic Groups of U.S. Middle-aged and Older-aged Women, Health Psychology (19) 354-64.

KUO F.E., BACAICOA M., SULLIVAN W.C. (1998) Transforming Inner City Landscapes: Trees, Sense of Safety, and Preference, Environment and Behavior (30) 28-59.

LAB S.P. (2000) Crime Prevention: Approaches, Practices and Evaluations, Anderson Publishing Company, USA.

LAWLINK NSW, (2000) CCTV Guidelines, [http://www.lawlink.nsw.gov. au/cpd.nsf/pages/cctv_intro] Access Date (2.05.2017).

LAWTON C.A., KALLAI J. (2002) Gender Differences in Wayfinding Strategies and Anxiety About Wayfinding: A Cross-cultural Comparison, Sex Roles (47) 389-401.

LOEWEN, J.L., STEEL, G.D., SUEDFELD, P. (1993) Perceived Safety from Crime in the Urban Environment, Journal of Environmental Psychology (13) 323-31.

LOUKAITOU-SIDERIS A., STIEGLITZ O. (2002) Children in Los Angeles parks: A Study of Equity, Quality and Children's Satisfaction with Neighborhood Parks, The Town Planning Review (73) 467-88.

LYNCH, K. (1960) The Image of the City, MIT Press, USA.

MADGE, C. (1997) Public parks and the Geography of Fear, Tijdschrift Voor Economische en Sociale Geografie (88) 237-50.

MARCUS C.C., FRANCIS C. (1998) People Places: Design Guidelines for Urban Open Space, Van Nostrand Reinhold, New York.

MC COY H.V., WOOLDREDGE J.D., CULLEN F.T., DUBECK P.J., BROWNING S.L. (1996) Lifestyles of the Old and not so Fearful: Life Situation and Older Persons' Fear of Crime, Journal of Criminal Justice (24) 191-205.

MÜDERRISOĞLU, H., DEMIR, Z. (2004) The Relationship Between Perceived Beauty and Safety in Urban Recreation Parks, Journal of Applied Sciences (1) 72-7.

NASAR J.L., FISHER B. (1993) Hot Spots' of Fear and Crime: A Multimethod Investigation, Journal of Environmental Psychology (13) 187206.

NASAR J.L., FISHER B., GRANNISA M. (1993) Proximate Physical Cues to Fear of Crime, Landscape and Urban Planning (26) 161-78. 
NASAR J.L., JONES K.M. (1997) Landscapes of Fear and Stress, Environment and Behavior (29) 291-323.

NORDH, H., ØSTBY, K. (2013) Pocket Parks for People-A Study of Park Design and Use, Urban Forestry \& Urban Greening (12) 12-7.

ORTEGA S., MYLES J. (1987) Race and Gender Effects on the Fear of Crime: An Interactive Model with Age, Criminology (25) 133-52.

ÖZGÜNER H., KENDLE A.D. (2006) Public Attitudes towards Naturalistic versus Designed Landscapes in the City of Sheffield (UK), Landscape and Urban Planning (74) 139-57.

PAIN R.H. (1997) Social Geographies of Women's Fear of Crime, Transactions of the Institute of British Geographers (22) 231-44.

PHILIPS, C. (1999) A Review of CCTV Evaluations: Crime Reduction Effects and Attitudes towards Its Use, Crime Prevention Studies (10) 123-55.

RELPH, E. (1976) Place and Placelessness, Pion, London.

SCARBOROUGH B.K., LIKE-HAISLIP T.Z., NOVAK K.J., LUCAS W.L., ALARID L.F. (2010) Assessing the Relationship between Individual Characteristics, Neighborhood Context, and Fear of Crime, Journal of Criminal Justice (38) 819-26.

SCHROEDER H.W., ANDERSON, L.M. (1984) Perception of Personal Safety in Urban Recreation Sites, Journal of Leisure Research (16) 17894.

SHAFFER G.S., ANDERSON L.M. (1985) Perceptions of the Security and Attractiveness of Urban Parking Lots, Journal of Environmental Psychology (5) 311-23.

STAMPS A.E. (2005) Enclosure and Safety in Urbanscapes, Environment and Behavior (37) 102-33.

TALBOT J.F., KAPLAN R. (1984) Needs and fears: The Response to Trees and Nature in the Inner City, Journal of Arboriculture (10), 222-8.

THOMPSON C.W. (2002) Urban Open Space in the 21st Century, Landscape and Urban Planning (60) 59-72.

VAN HERZELE A., WIEDEMANN T. (2003) A Monitoring Tool for the Provision of Accessible and Attractive Urban Green Spaces, Landscape and Urban Planning (63) 109-26.

WARR M. (1990) Dangerous Situation: Social Context and Fear of Victimization, Social Forces (68) 891-907.

WEISMAN J. (1981) Evaluating Architectural Legibility, Environment and Behavior (13) 189-204.

WEISMAN J. (1987) Improving Way-finding and Architectural Legibility in Housing for the Elderly, Housing the Aged: Design Directives and Policy Considerations, eds. V. Regnier, J. Pynoos, Elsevier, New York; 441-64.

WEKERLE G.R., WHITZMAN C. (1994) Safer Cities: Guidelines for Planning, Design and Management, Van Nostrand Reinhold, New York.

WELSH B.C., FARRINGTON, D.P. (2009) Public Area CCTV and Crime Prevention: An Updated Systematic Review and Meta-Analysis, Justice Quarterly (68) 716-45. 
Alındı: 19.02.2015; Son Metin: 23.09.2016

Anahtar sözcükler: Kent parkları; güvenlik algısı; Büyükpark; Hasanağa Parkı; İzmir.
WESTOVER T.N. (1985) Perceptions of Crime and Safety in Midwestern Parks, the Professional Geographer (37) 410-20.

WESTOVER T.N. (1986) Park Use and Perception: Gender Differences, Journal of Park and Recreation Administration (4) 1-8.

ZAKARIAN J.M., HOVELL M.F., HOFSTETTER C.R., SALLIS J.F., KEATING K.J. (1994) Correlates of Vigorous Exercise in a Predominantly Low SES and Minority High School Population, Preventative Medicine (23) 314-21.

\section{KENT PARKLARINDA GÜVENLİK ALGISININ İRDELENMESİ: BÜYÜKPARK VE HASANAĞA PARKINDA BİR ALAN ÇALIŞMASI}

Güvenlik algısı pek çok potansiyel park kullanıcısını kamusal açık mekanları kullanmaktan ve bu mekanlarda hoşça vakit geçirmekten alıkoyan önemli bir faktördür. Güvenlik algısıyla ilişkili olan suç korkusu konusunda doğal çevrelerde ve parklarda pek çok araştırma gerçekleştirilmiştir. Ancak mevcut literatürde, parklardaki güvenlik algısını suç korkusunun ötesinde daha geniş bir çerçevede ele alan, açıklayan ve ölçümleyen bir çalışma yer almamaktadır. Bu çalışmanın temel amacı, kent parklarında güvenlik algısını değerlendiren bir ölçek geliştirmek, hangi değişkenlerin güvenlik algısını nasıl etkilediğini açıklamak ve güvenlik algısının park kullanımına olan etkisini irdelemektir. Araştırmanın uygulamalı alan çalışması bölümünde, İzmir kentinde Cumhuriyet Dönemi sonrasında yapılan kent parkları taranarak, literatürde güvenlik algısını etkilediği tespit edilen çevresel özellikler açısından (kentsel konum, peyzaj, çevresel tasarım, bakım ve aydınlatma) olumlu ve olumsuz faktörleri tipik olarak örnekleyen iki kent parkı inceleme alanı olarak belirlenmiştir. İncelenen parklar arasında güvenlik açısından olumlu çevresel özellikler taşıyan Büyükpark Bornova'da, görece olumsuz özellikler taşıyan Hasanağa Parkı ise Buca'da konumlanmaktadır. 442 kişiye yüz yüze uygulanan anket çalışması sonucunda güvenlik algısının yalnızca suç korkusu ile açıklanamayacağı, yer yön bulma endişesi ve çevresel doyum duygusunun güvenlik algısını açıklayan önemli faktörler olduğu belirlenmiştir. Çalışmanın sonucunda, park tasarım ve planlama çalışmalarında kullanıcıların güvenlik algısını olumlu yönde geliştirmek için suç korkusunu engelleyen çevresel tasarım özelliklerinin yanı sıra yer yön bulma endişesini azaltan ve kullanıcı doyumunu iyileştiren yaklaşımların da dikkate alınması gerektiği ortaya çıkmıştır. Yapılan istatistik analizlerde iki parkın kullanıcılarının güvenlik algılarının düzeyi kıyaslanmış ve olumlu çevresel özelliklere sahip olan Büyükpark kullanıcılarının Hasanağa Parkı kullanıcılarına göre kendilerini daha güvende hissettikleri bulunmuştur. Bu sonuç, çevresel tasarımın güvenlik algısındaki rolünü ortaya koymuş, kent merkezinde konumlanan, görece kontrollü ve küçük, özel olarak tasarlanmış, bakımlı ve bol aktivite sunan kent parklarının daha güvenli algılandığını göstermiştir. Sosyo-demografik özelliklerden cinsiyet, yaş, medeni hal ve eğitim düzeyinin parklardaki güvenlik algısını etkilediği ayrıca, güvenli algılanan parkların daha sık ziyaret edildiği de tespit edilmiştir. 


\section{ANALYSIS OF PERCEIVED SAFETY IN URBAN PARKS: A FIELD STUDY IN BÜYÜKPARK AND HASANAĞA PARK}

Perceived safety is an important factor that may discourage many potential visitors from using and enjoying available public open spaces. Significant number of research have been conducted on different kinds of public open spaces including natural environments and parks with a particular focus on fear of crime related to perceived safety. However, no research has been met in current literature that handles, explains, and measures perceived safety in a broader sense in urban parks beyond fear of crime. The main aims of this study is to a) develop a scale to measure perceived safety in urban parks, b) find out the key factors that affect perceived safety and c) examine the impact of perceived safety on utilization of urban parks. During field study, urban parks constructed after Republican Period in İzmir were surveyed and two prominent urban parks with different environmental features were selected as case studies of the research (urban location, landscape and environmental design, maintenance and lighting). While Büyükpark, which has considerable environmental features, is located in Bornova district, Hasanağa Park that can be characterized by negative environmental features, is located in Buca region in İzmir. The study, which was conducted through on-site observations and face to face questionnaires with 442 people, concludes that perceived safety cannot be explained only with fear of crime. Wayfinding and environmental satisfaction also appear as significant parameters for perceived safety in urban parks. The study also indicates that design of urban parks should not only target prevention of fear of crime but also enhance wayfinding ability and environmental satisfaction of users through appropriate design techniques and strategies. In statistical analyses, perceived safety responses of users of the two park were compared. The comparison shows that users of Büyükpark (with positive design features) are more satisfied with safety situation in the park than users of Hasanağa Park. Another significant result of the research is that urban parks in central locations of cities are perceived as safer if they are relatively small, easy to control, well-maintained and include various activities. Socio demographic factors such as gender, age, marital status and education level are also found as significant factors that affect safety perception of park users. Additionally, increased safety perception results in more frequent visit to urban parks.

ILKNUR TÜRKSEVEN DOĞRUSOY; B. Arch, MSc, Phd.

Received her bachelor's degree in architecture from Dokuz Eylül University (1990-1994). She earned her Msc (1994-1996) and Ph.D (1997-2002) degrees in architecture from Graduate School of Natural and Applied Sciences at Dokuz Eylül University. Major research interests include environmental psychology, urban and public open spaces and sustainable architecture. ilknur.turkseven@deu.edu.tr

RENGIN ZENGEL; B. Arch, MSc., Phd.

Received her bachelor's degree in Architecture from Dokuz Eylül University (1986-1990). She earned her Msc and Ph.D degrees in architecture from Graduate School of Natural and Applied Sciences in Dokuz Eylül University in 1993 and 1998 respectively. Major research interests include post-occupancy evaluations of multi-purpose buildings, public outdoor spaces, basic design and education-creativity relations, and architecture-environment relations. rengin.zengel@deu.edu.tr 